\title{
Biomass Reburning - Modeling/Engineering Studies
}

\author{
Quarterly Report No. 10 for Period \\ January 1 - March 31, 2000 \\ Prepared by: \\ Vladimir Zamansky, David Moyeda and Mark Sheldon
}

April 28, 2000

DOE Contract No. DE-FC26-97FT97270

\begin{abstract}
Submitted by:
GE Energy and Environmental Research Corporation
\end{abstract}

18 Mason, Irvine, CA 92618 


\section{$\underline{\text { Disclaimer }}$}

This report was prepared as an account of work sponsored by an agency of the United States Government. Neither the United States nor any agency thereof, nor any of their employees, makes any warranty, express or implied, or assumes any legal liability or responsibility for the accuracy, completeness, or usefulness of any information, apparatus, product, or process disclosed, or represents that its use would not infringe privately owned rights. Reference herein to any specific commercial product, process, or service by trade name, trademark, manufacturer, or otherwise does not necessarily constitute or imply its endorsement, recommendation, or favoring by the United States Government or any agency thereof. The views and opinions of authors expressed herein do not necessarily state or reflect those of the United States Government or any agency thereof. 


\begin{abstract}
This project is designed to develop engineering and modeling tools for a family of $\mathrm{NO}_{\mathrm{x}}$ control technologies utilizing biomass as a reburning fuel. During the tenth reporting period (January 1 March 31, 2000), EER and NETL R\&D group continued to work on Tasks 2, 3, 4, and 5. Information regarding these tasks will be included in the next Quarterly Report. This report includes (Appendix 1) a conceptual design study for the introduction of biomass reburning in a working coal-fired utility boiler. This study was conducted under the coordinated SBIR program funded by the U. S. Department of Agriculture.
\end{abstract}




\section{Table of Contents}

$\underline{\text { Section }}$

$\underline{\text { Page }}$

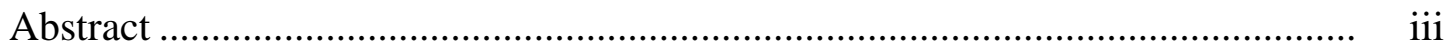

1.0 Project Status and Progress during the Reporting Period ............................. 1

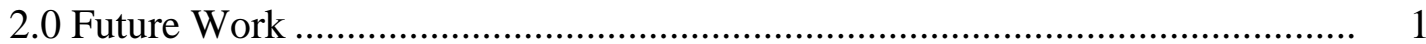

Appendix 1.

Conceptual Design Studies for Biomass Reburning

and Advanced Biomass Reburning ...................................................... A-1 


\section{Project Status and Progress During the Reporting Period}

This project is designed to develop engineering and modeling tools for a family of $\mathrm{NO}_{\mathrm{x}}$ control technologies utilizing biomass as a reburning fuel. Basic and advanced biomass reburning technologies have the potential to achieve $60-90+\% \mathrm{NO}_{\mathrm{x}}$ control in coal fired boilers at a significantly lower cost than SCR. Project participants include: GE Energy and Environmental Research Corporation (EER), NETL R\&D group, Niagara Mohawk Power Corporation (NMPC) and Antares, Inc. Project tasks, responsibilities of organizations, and current task status are as follows:

1. Kinetic Modeling of Biomass Reburning (EER) - completed

2. Computational Fluid Dynamics (CFD) Modeling (NETL) - in progress

3. Physical Modeling (EER) - in progress

4. Biomass Preparation Economics (NETL) - in progress

5. Evaluation of Slagging and Fouling (NETL) - in progress

6. Reburning vs. Cofiring Evaluation (Antares) - completed

7. Project Management and Reporting - in progress

This NETL project is conducted in close coordination with EER's Phase II SBIR project funded by USDA. The division of tasks between the two projects was thought out to keep process optimization and design tasks within the SBIR project. The FETC project involves modeling activities, economic studies of biomass handling, and experimental evaluation of slagging and fouling.

During the reporting period, project activities included selection of a boiler for engineering and modeling studies, physical flow modeling (Task 3 - currently in progress), preparation for CFD studies (Task 2 - NETL), and Management/Reporting (Task 7). This report includes data (Appendix 1) on engineering design studies being conducted under the coordinated SBIR program funded by the U. S. Department of Agriculture.

As noted in previous reports, Niagra Mohawk withdrew from a proposed demonstration agreement following a change in ownership. At this time, a host site agreement has not yet been reached with any other candidate site. To complete the program objectives, process design work has begun on the basis of a typical boiler design. The boiler selected is a tangentially fired furnace using coal as the primary fuel. EER has previously conducted reburning studies on this boiler, and so already has the benefit of experience for evaluating this unit. A preliminary study in which process flows and projected NOx reduction performance are assessed is provided as Appendix 1.

\section{Future Work}

It is anticipated that major part of Tasks 2,4 and 5 will be completed by NETL R\&D group during the next quarter. EER also plans to conclude its studies under Task 3. The results will be reported in the next quarterly report. 
Appendix 1.

\section{Conceptual Design Studies for Biomass Reburning and Advanced Biomass Reburning}

\subsection{Introduction}

GE Energy and Environmental Research Corporation (GE EER) developed a methodology for the scale up and application of reburning technologies to coal-fired boilers. This methodology has been successfully used for design of reburning systems employing natural gas and coal as the reburning fuel. One of the objectives of GE EER's biomass reburning studies is to adapt this methodology to the design of a reburning system using biomass as the reburning fuel. This methodology will then be used to design a full-scale system for a coal-fired boiler in a demonstration of the technology. At this time, GE EER has not identified a specific host site for the demonstration phase of the project. Therefore, the scale up studies will be performed on a typical coal-fired boiler.

In considering the use of biomass as a reburning fuel for reburning and advanced reburning technologies, a number of important questions need to be addressed:

1) What design specifications are needed to ensure effective mixing of the biomass particles with the furnace flue gases?

2) How does biomass reburning and advanced biomass reburning impact the boiler thermal performance and efficiency?

3) How does biomass particle size impact carbon burnout?

4) What is the best approach for injecting reagent in advanced biomass reburning?

Each of these issues can impact the performance and costs for applying biomass reburning technologies to a specific unit.

As a first step in addressing these issues, GE EER has developed a conceptual design for the application of reburning biomass technology and advanced biomass reburning technologies to a typical coal-fired boiler selected from an internal database on coal-fired boilers. The conceptual design will be evaluated in more detail in order to address the specific issues identified above. The conceptual design was first developed by performing a review of the boiler characteristics to define a potential approach for installing reburning technologies to the unit. This approach was then used to develop a preliminary conceptual design for reburning and advanced reburning systems using biomass, and to project the $\mathrm{NO}_{\mathrm{x}}$ control performance that might be achievable.

This report includes a brief description of the reburning and advanced reburning process, GE EER's recommended approach for applying biomass reburning technologies to the unit, and preliminary $\mathrm{NO}_{\mathrm{x}}$ control projections. This design will be evaluated in more detail in coming months. 
Reburning is a combustion modification technology that removes $\mathrm{NO}_{\mathrm{x}}$ from combustion products by using fuel as a reducing agent and is based on the principle that hydrocarbon fragments can react with NO. Reburning can be applied to any type of utility boiler firing configuration. The reburning fuel can be the same as the primary fuel or it can be a different fuel such as coal, biomass, gas, or fuel oil. Conventional reburning technology is applied to a utility boiler by the staged addition of fuel and air to the boiler furnace following the main burners or primary combustion zone. The process can be divided conceptually into three zones as illustrated in Figure 2-1.

Primary Zone: During reburning, the primary combustion zone will account for approximately 80 percent of the total heat input. In this zone, the primary fuel will be burned under fuel lean conditions. In most cases, the air/fuel ratio to the main burners can be reduced which will lower the initial $\mathrm{NO}_{\mathrm{x}}$ entering the reburning zone, and reduce the amount of reburning fuel necessary to achieve optimum conditions for $\mathrm{NO}_{\mathrm{x}}$ reduction in the reburning zone.

Reburning Zone: Above the main burners, additional fuel is added to create a slightly fuel rich environment or "reburning zone" which reduces nitrogen oxides formed in the primary combustion zone to molecular nitrogen. Depending upon the primary excess air level, the reburning fuel typically accounts for up to 20 percent of the total heat input. The process begins when hydrocarbon radicals formed from the reburning fuel in the fuel rich reburning zone, primarily $\mathrm{CH}$ species, react with $\mathrm{NO}$ from the primary zone to form other nitrogen species such as $\mathrm{HCN}$ and $\mathrm{NH}_{3}$. Once formed, these species rapidly react with other primary $\mathrm{NO}$ molecules to form molecular nitrogen $\left(\mathrm{N}_{2}\right)$. EER has extensively studied the reduction of $\mathrm{NO}$ to molecular nitrogen in the reburning process.

Burnout Zone: Following the reburning zone, overfire air is added to the boiler to produce overall lean conditions and to oxidize carbon monoxide and any remaining fuel fragments exiting the reburning zone. The remaining fixed nitrogen species will either be oxidized to $\mathrm{NO}_{\mathrm{x}}$ or reduced to molecular nitrogen.

In advanced reburning technology, a $\mathrm{NO}_{\mathrm{x}}$ reducing reagent (such as urea or ammonia) is added to the reburning process to further reduce $\mathrm{NO}_{\mathrm{x}}$ emissions. The reagent can be added before, with or after the overfire air depending upon the flue gas temperature at the point of overfire air injection. Although advanced reburning is essentially the combination of gas reburning with selective non-catalytic reduction (SNCR) technology, its implementation combines the technologies in a fashion that reduces the cost of SNCR implementation and can improve performance of the reagent injection step.

GE EER has completed pilot-scale studies of biomass reburning. These studies have been summarized in previous reports, particularly Quarterly Reports No. 2 through 4. A number of pulverized biomass fuels were tested, including willow wood (23\% through 200 mesh), walnut shells (55\% through 200 mesh), and furniture waste (48\% through 200 mesh for most tests). Common conditions for the experiments were a primary zone stoichiometric ratio (SR) of 1.10, a final SR of 1.15, and reburn fuel injected at a combustion gas temperature of about $1700 \mathrm{~K}$. Performance on the basis of percent $\mathrm{NO}_{\mathrm{x}}$ reduction improved as the level of initial $\mathrm{NO}_{\mathrm{x}}$ increased. Basic reburning performance improved with increased reburn fuel heat input, except for furniture waste biomass when injected with inert carrier gas (which showed peak 
performance at $15 \%$ heat input). However, this performance peak did not reflect most biomass fuels tested and also disappeared for furniture waste when air was used as the carrier gas, which is more reflective of the type of carrier anticipated in actual practice (that is, containing some amount of oxygen). Performance improved as the reburn zone residence time increased and overfire air injection temperature correspondingly decreased; in practice the OFA injection temperature needs to be set at a practical level to achieve good mixing and burnout of rich reburning flue gas within the furnace.

For experiments in which N-agents were introduced (Advanced Reburning or Reburning+SNCR), good performance was found for NSR of about 1.5. The maximum $\mathrm{NO}_{\mathrm{x}}$ performance of all conditions tested was $83 \%$ for Reburn+SNCR with Willow wood at an SNCR of 1.45 , after OFA injection at $1450 \mathrm{~K}$ and urea injection at $1310 \mathrm{~K}$. Under similar conditions, Reburn+SNCR using furniture waste provided about $76 \% \mathrm{NO}_{\mathrm{x}}$ reduction.

A number of factors can influence the performance of reburning and advanced reburning on a particular utility boiler. The boiler design impacts the locations where reburning fuel injectors and overfire air ports can be installed, and ultimately dictates the reburning zone residence time and thermal environment, both of which have a first order impact on reburning performance. The boiler design also largely controls the characteristics of the gas flow path in the furnace, which determines how effectively and how fast the reburning process streams can be mixed into the bulk furnace flow. The firing configuration of the boiler also influences the process, since it determines the $\mathrm{NO}_{\mathrm{x}}$ levels and the temperature of the gases entering the reburning zone. In general, the $\mathrm{NO}_{\mathrm{x}}$ control performance of reburning increases as the level of $\mathrm{NO}_{\mathrm{x}}$ emissions entering the process and the gas temperatures at the point of reburning fuel introduction increases. Application of Advanced Reburning to a specific boiler requires a very site-specific analysis to assess furnace flow fields and temperature profiles for optimum location and design of the reagent injectors.

\subsection{Reburning Application}

The boiler selected for the scale-up studies is a tangentially fired boiler manufactured by Combustion Engineering and has a rated capacity of $170 \mathrm{MW}$ (gross). The unit was designed to burn and presently fires Eastern bituminous coal with a nominal heating value of $12,381 \mathrm{Btu} / \mathrm{lb}$. At full load firing pulverized coal, the unit has a gross heat input of 1,427 MMBtu/hr. As shown in Figure 3-1, the unit is equipped with low- $\mathrm{NO}_{\mathrm{x}}$ burners and close-coupled overfire air ports (CCOFA). There are four coal nozzles in the burners. One mill provides coal to the four nozzles located on the furnace corners at each elevation. Flue gas from the flames passes from the lower furnace into the upper furnace and then into the rear convective pass.

At full load, $\mathrm{NO}_{\mathrm{x}}$ emissions vary from 0.28 to $0.38 \mathrm{lb} / \mathrm{MMBtu}$, depending upon specific operating and burner settings. Average $\mathrm{NO}_{\mathrm{x}}$ emissions are $0.32 \mathrm{lb} / \mathrm{MMBtu}$. As load is reduced, $\mathrm{NO}_{\mathrm{x}}$ emissions are reduced and reach $0.27 \mathrm{lb} / \mathrm{MMBtu}$ at $50 \%$ load. The normal excess air level of the unit at full load is approximately 20\%. Carbon-in-ash levels are typically in the range of 5 to $10 \%$.

The biomass composition used for conceptual design studies is similar to that of pulverized furniture waste used in earlier pilot scale studies under this program. The composition 
TABLE 3-1. FUEL ANALYSIS

\begin{tabular}{||l|c|c|c||}
\hline \hline \multicolumn{1}{|c|}{ Parameter } & Units & Coal $^{*}$ & $\begin{array}{c}\text { Furniture } \\
\text { Waste }\end{array}$ \\
\hline \hline Ultimate analysis & & & \\
\hline Carbon & $\%$ dry & 77.78 & 53.81 \\
\hline Hydrogen & $\%$ dry & 4.63 & 6.06 \\
\hline Nitrogen & $\%$ dry & 1.48 & 0.56 \\
\hline Sulfur & $\%$ dry & 0.83 & 0.03 \\
\hline Oxygen (difference) & $\%$ dry & 5.97 & 38.05 \\
\hline Ash & $\%$ dry & 9.31 & 1.31 \\
\hline Chlorine & $\%$ dry & -- & 0.19 \\
\hline Moisture & $\begin{array}{c}\% \text { as } \\
\text { fired }\end{array}$ & 6.47 & 7.33 \\
\hline Higher Heating Value & $\begin{array}{c}\text { Btu/lb } \\
\text { dry }\end{array}$ & 13,237 & 8,507 \\
\hline
\end{tabular}

* Eastern Bituminous coal currently fired at example plant.

parameters which entered into the current analysis (ultimate analysis and heating value) are shown in Table 3-1 for both the coal used in this boiler and the biomass.

GE EER has identified a preliminary approach for applying biomass and advanced biomass reburning to the unit as illustrated in Figure 3-2. In both processes, the reburning fuel would be injected at an elevation above the main burners, and the overfire air would be injected at an elevation selected to provide the maximum reburning zone residence time within the furnace constraints. As shown in Figure 3-2, the reburning fuel injectors would be located approximately eight feet above the upper coal nozzles on the furnace corners. This elevation is above the burners, and should provide sufficient separation between the main flames and the reburning zone to ensure good reburning performance. Overfire air injectors would be located on the furnace corners at an elevation approximately ten feet above the reburning fuel injectors. The overfire air system would be designed to provide good control over carbon monoxide emissions and burnout of the biomass and coal particles. For this unit, GE EER would install the reagent injectors within the overfire air injectors. The droplet size would be optimized to permit delivery of reagent into the proper temperature window. Based upon the above, the conceptual design described below was developed.

The reburning fuel injectors would be installed on each corner of the furnace to promote mixing of the reburning fuel. For the use of biomass as a reburning fuel, preliminary calculations suggest that the use of a total of four injectors would result in effective mixing of the reburning fuel with the furnace gases. Each injector would consist of a single reburning fuel nozzle with a diameter of between 10 to 15 inches depending upon the mill and transport requirements. Injection velocities in the range of $150 \mathrm{feet} / \mathrm{sec}$ are expected to be required to achieve good mixing of the reburning fuel. The injection velocity is linked to the amount of transport gas (air or recycled flue gas) that is required by the biomass mill and to transport the biomass from milling/storage to the injection location. This parameter should be evaluated in further studies. 
The overfire injection system would consist of four dual-compartment OFA injectors installed at each corner of the furnace. The dual-compartment OFA injectors consist of a constant velocity zone and a modulating velocity zone. This feature permits individual tuning of the OFA injectors to bias flow conditions according to furnace flow patterns, and the capability of operating over a wider range of reburning conditions. In general, sufficient mixing should be attainable using the existing windbox pressure. However, this is also a parameter that should be evaluated in further studies.

For implementation of advanced reburning, a preliminary analysis suggests that the most costeffective approach would be to locate the reagent injectors within the overfire air ports. This approach would minimize the retrofit costs and should provide good SCNR performance. The size distribution of the reagent spray would need to be optimized to deliver the reagent within the proper window. In further studies, GE EER will evaluate the specific droplet size requirements and their impacts on $\mathrm{NO}_{\mathrm{x}}$ reduction.

Preliminary process flow diagrams for the application of biomass reburning and advanced biomass reburning to the unit are shown in Figures 3-3 and 3-4. Material balances corresponding to these two process flow diagrams are shown in Tables 3-2 and 3-3. For biomass reburning, the system would be sized for operation at $170 \mathrm{MW}$. The primary excess air level in the burners would be lowered from $20 \%$ to $10 \%$ in order to minimize the amount of reburning fuel needed to achieve a specific $\mathrm{NO}_{\mathrm{x}}$ emissions target. Sufficient overfire air would be added to bring the boiler up to its normal operating excess air level of $20 \%$. In the reburning zone, the target is to achieve an overall stoichiometric ratio of 0.90 , which is optimal for $\mathrm{NO}_{\mathrm{x}}$ reduction when using biomass. For these criteria, the reburning fuel represents approximately 20 percent of the total boiler heat input (based upon the use of recycled flue gas as the reburning fuel transport and injection medium). It is possible to reduce the amount of natural gas used to achieve a specific $\mathrm{NO}_{\mathrm{x}}$ target by lowering the burner excess air level below $10 \%$. The potential to lower the burner excess air level and its impacts on operation of the lower furnace and carbon loss need to be evaluated in a more detailed assessment. For advanced reburning, the operation of the reburning system would be similar to that described above. The design point for the reagent injection system would be to achieve a nitrogen stoichiometric ratio (NSR) of 1.5.

\section{0 $\quad \mathrm{NO}_{\mathrm{x}}$ Control Performance}

A preliminary projection of the impacts of reburning and advanced reburning with biomass on $\mathrm{NO}_{\mathrm{x}}$ emissions from the tangentially fired boiler has been developed. The projected emissions performance curves are shown in Figure 4-1.

The emissions performance curves are based on the range of performance trends seen for different biomass fuels studied in the experimental program. They do not include the peak in performance at about $15 \%$ reburning heat input which was seen only for furniture waste, and only with nitrogen as the carrier gas. (Depending on economic analysis to be conducted, the preferred carrier gas could be either air, which is easy to handle but reduces $\mathrm{NO}_{\mathrm{x}}$ reduction performance, or recirculated flue gas, which gives better performance but requires higher capital costs.) Even though the composition used in process design calculations was that of furniture waste, the projections here are designed to be more generally applicable to a variety of biomass fuels. Fuel-specific issues will be considered further in later studies. 
At full load, it is expected that biomass reburning should be capable of reducing $\mathrm{NO}_{\mathrm{x}}$ emissions from a baseline of $0.32 \mathrm{lb} / \mathrm{MMBtu}$ to $0.19 \mathrm{lb} / \mathrm{MMBtu}$, which represents a 40 percent reduction in $\mathrm{NO}_{\mathrm{x}}$ emissions. This level of $\mathrm{NO}_{\mathrm{x}}$ emissions should be achievable with approximately 20 percent of the boiler heat input supplied by the reburning fuel, depending upon the acceptable burner excess air level. A preliminary estimate of the application of advanced biomass reburning to the tangentially fired boiler indicates that $\mathrm{NO}_{\mathrm{x}}$ emissions levels of 0.17 or below could potentially be reached.

These estimates of the potential $\mathrm{NO}_{\mathrm{x}}$ control levels achievable with reburning and advanced reburning should be considered preliminary pending a more detailed analysis of the furnace gas temperatures, residence times, and flow patterns.

\subsection{Summary}

Based upon this preliminary evaluation, GE EER believes that reburning and advanced reburning technologies can be successfully applied using biomass. Pilot-scale studies on biomass reburning conducted by GE EER have indicated that biomass is an excellent reburning fuel. A preliminary conceptual design has been developed for a typical coal-fired boiler. GE EER plans on performing additional design studies to evaluate the potential to achieve good mixing of the reburning fuel, overfire air, and reagent within the boiler under evaluation and the potential impacts of reburning and advanced reburning on boiler performance, and will use this information to develop guidelines for the application of biomass and advanced biomass reburning technologies to coal-fired boilers. 


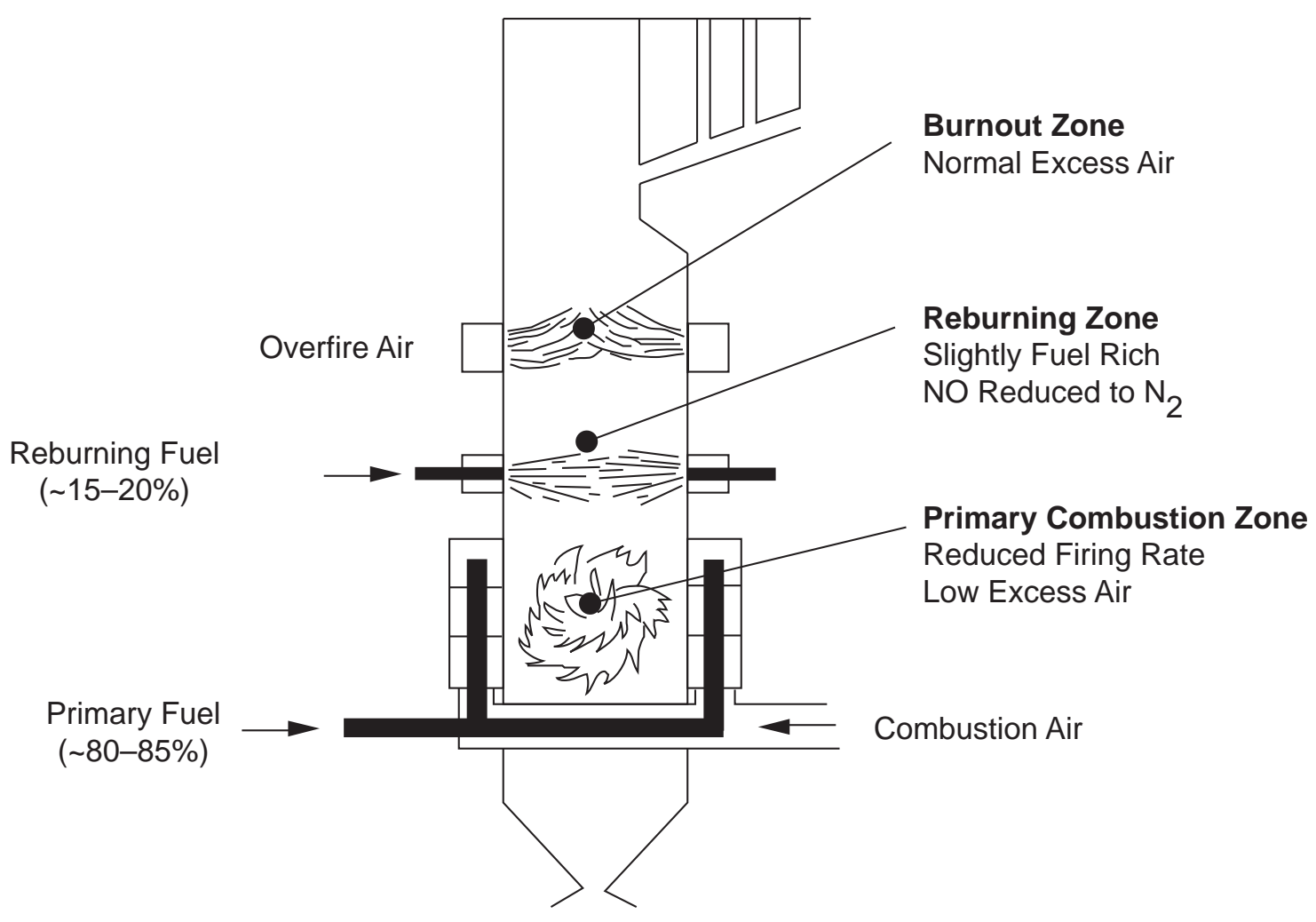

Figure 2-1. Application of reburning to a utility boiler. 


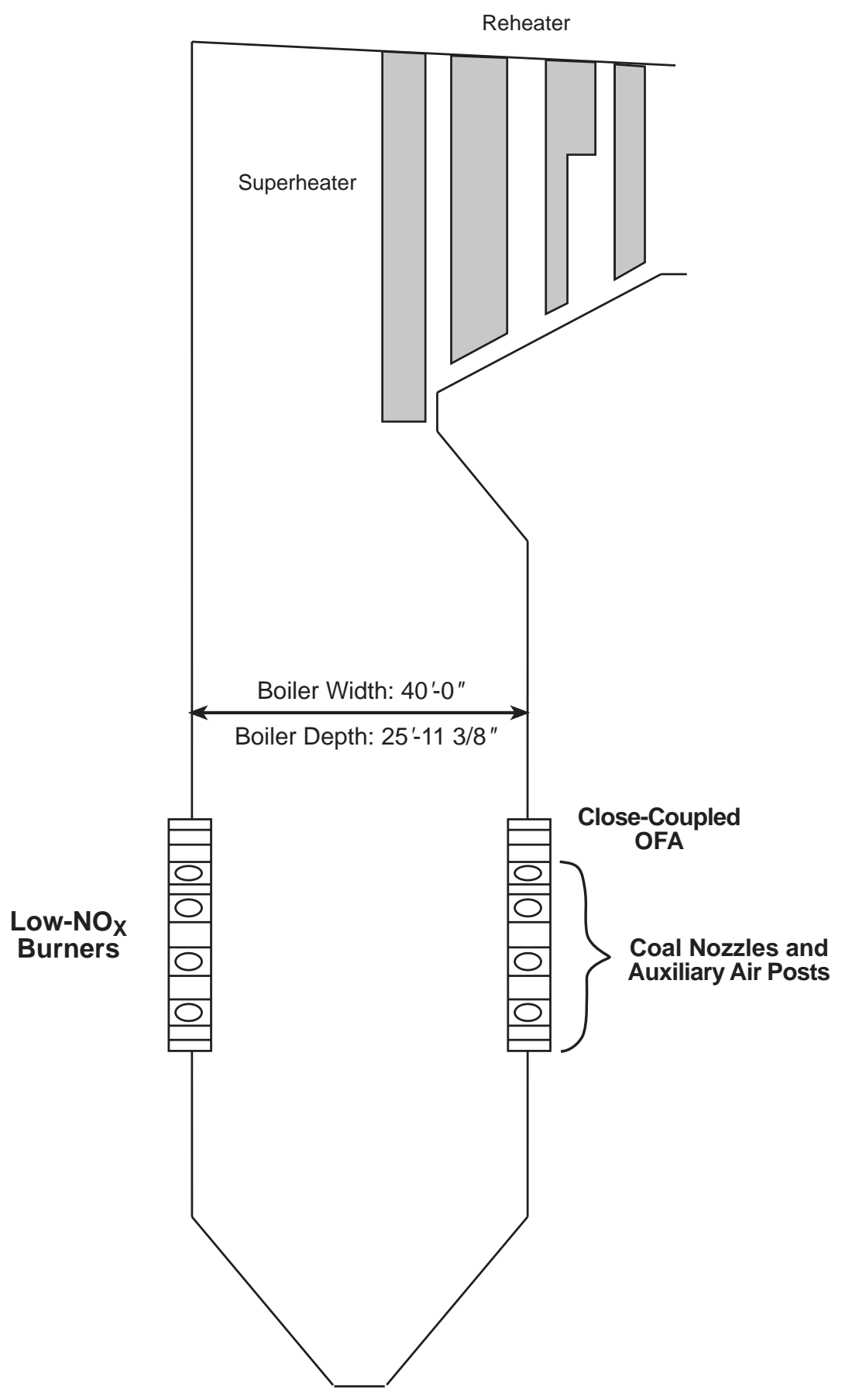

Figure 3-1. Sideview of typical tangentially fired boiler. 


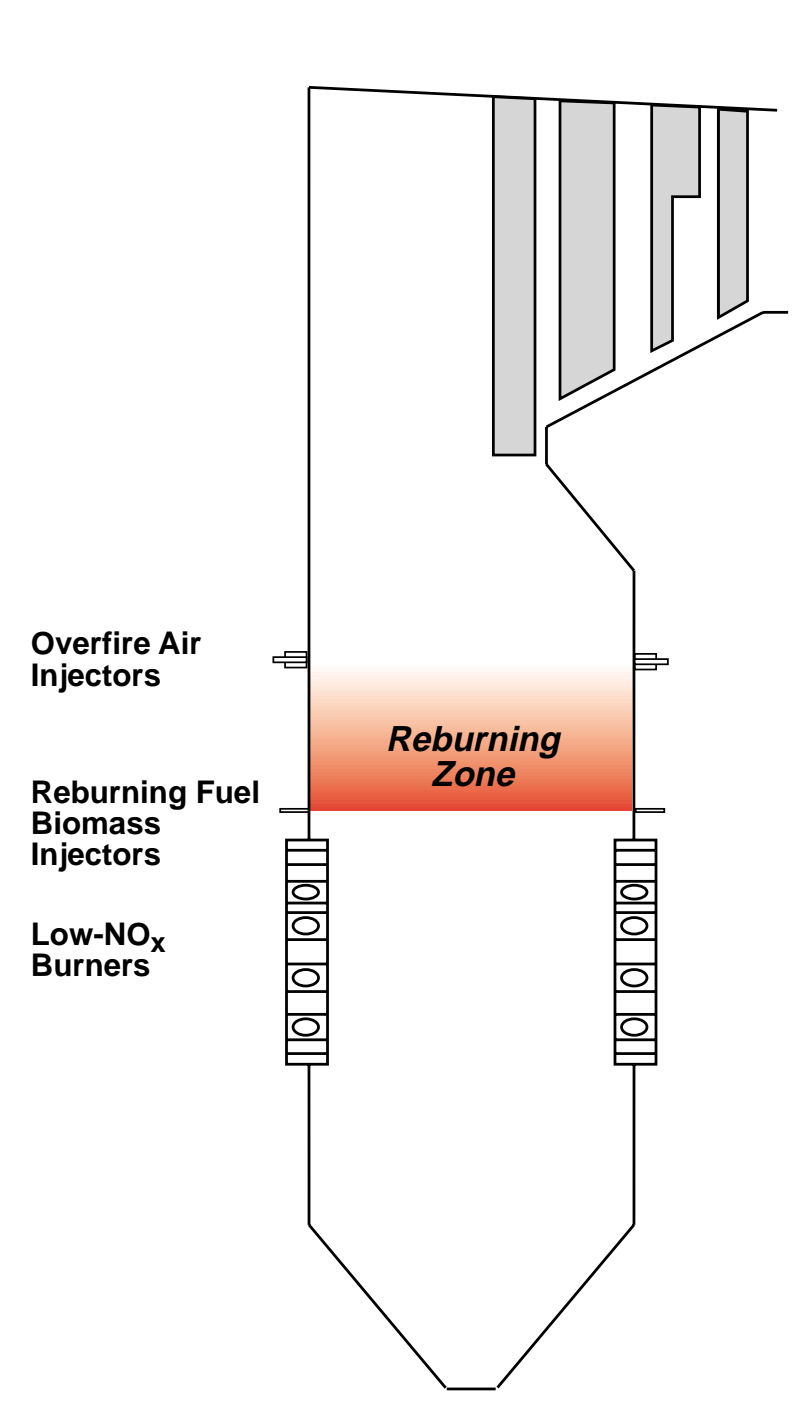

(a) Biomass reburning.

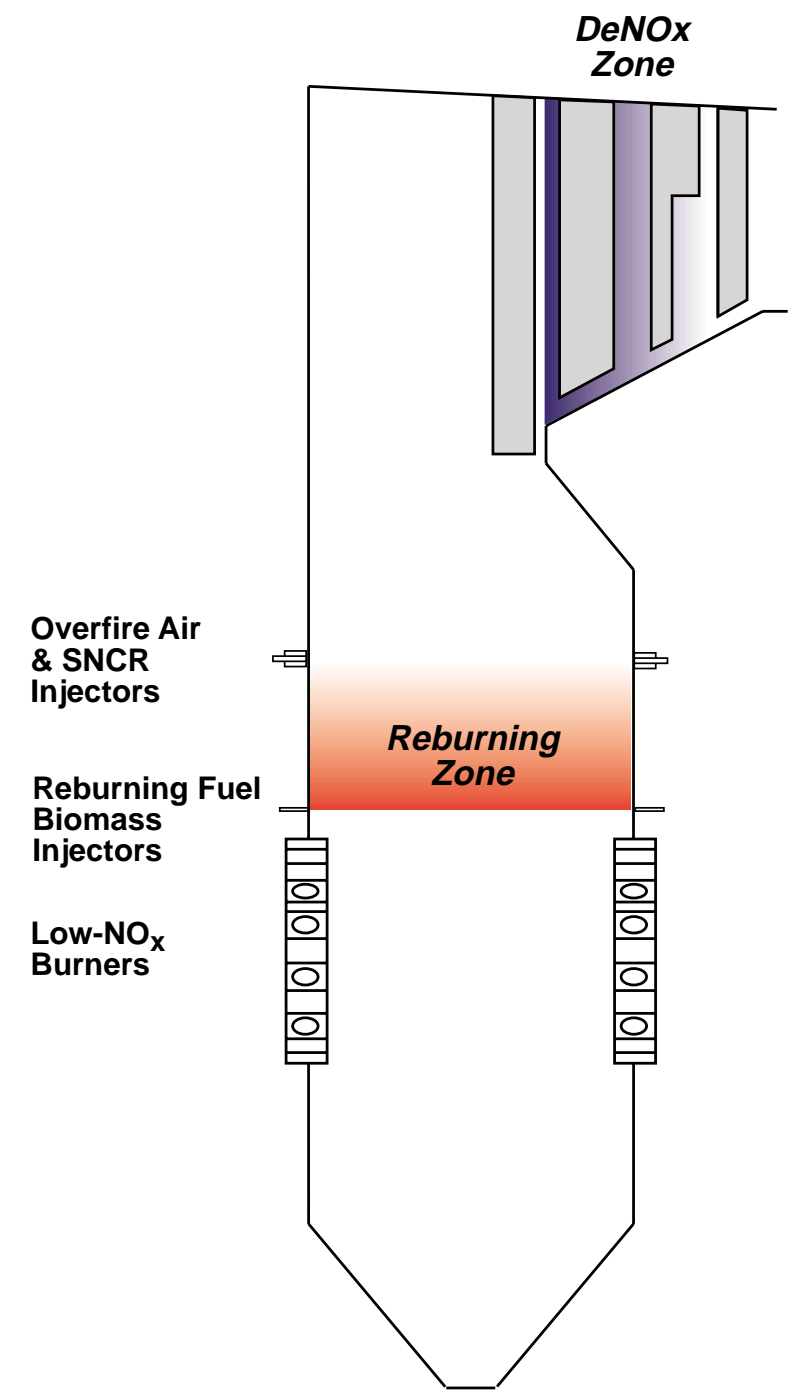

(a) Advanced biomass reburning.

Figure 3-2. Application of biomass reburning technologies to typical tangentially fired boiler. 


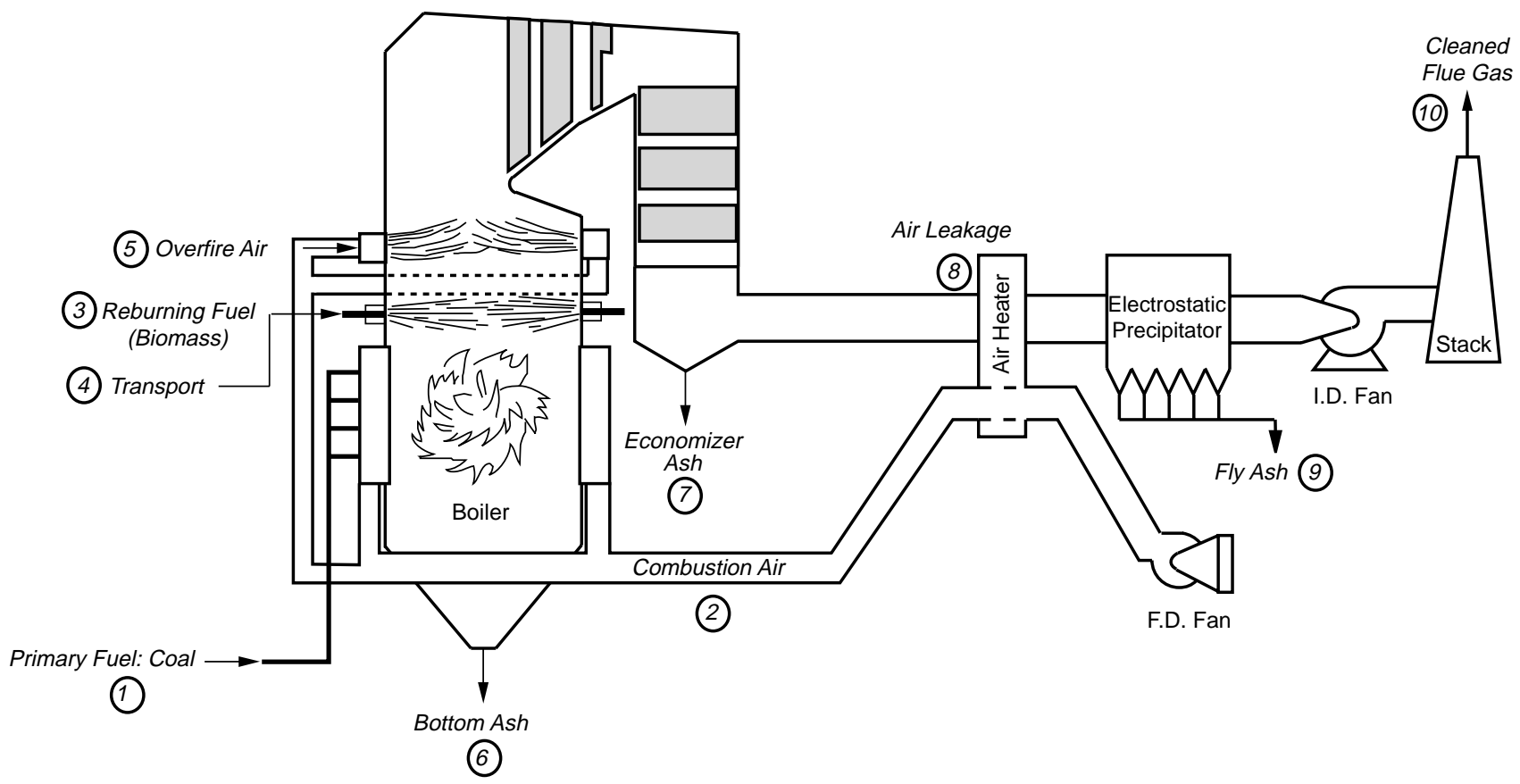

Figure 3-3. Process flow diagram for biomass reburning application. 


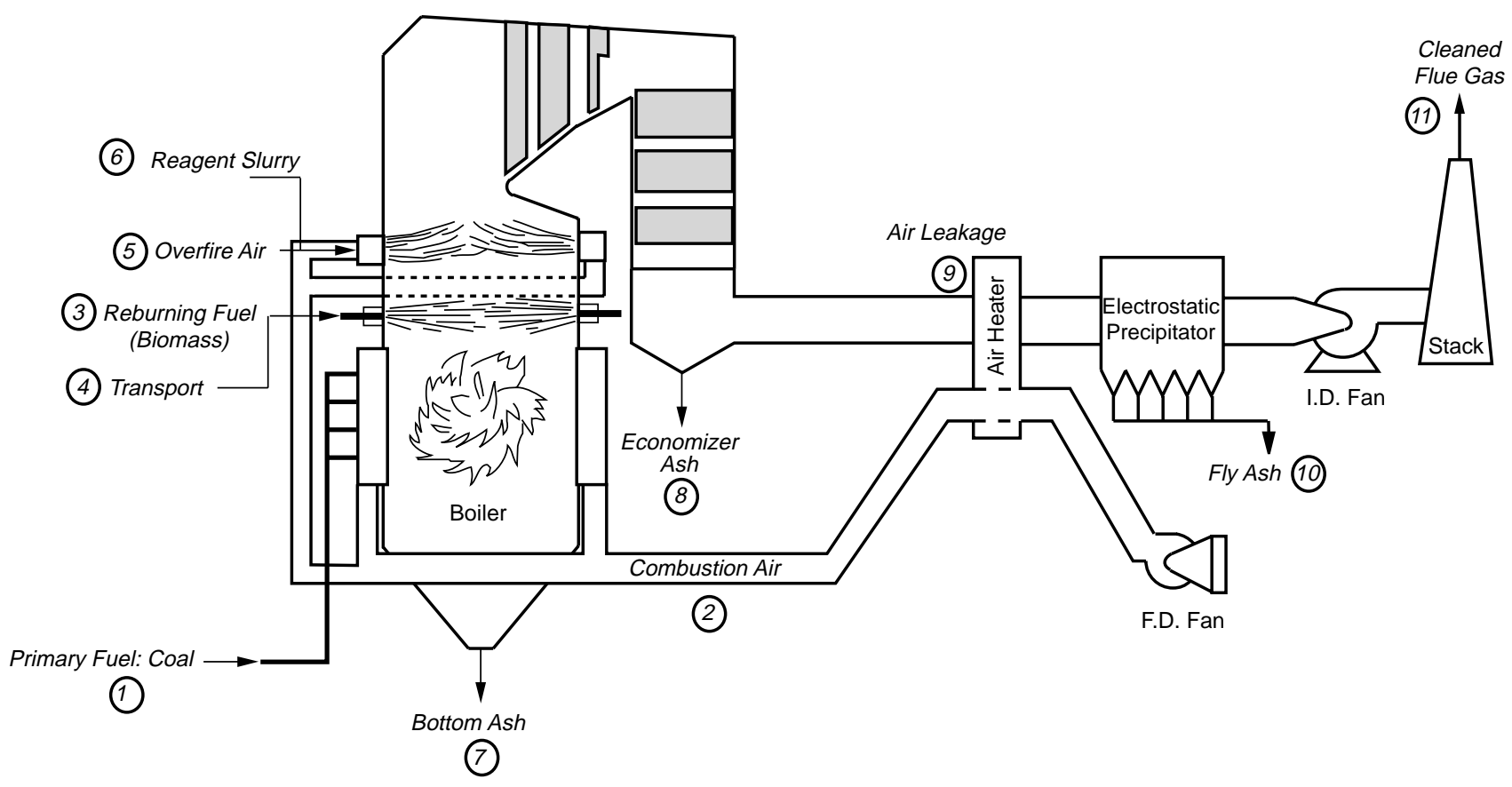

Figure 3-4. Process flow diagram for advanced biomass reburning application. 
TABLE 3-2. REBURNING MATERIAL BALANCE

\begin{tabular}{|c|c|c|c|c|c|c|c|c|c|c|}
\hline STREAM NUMBER & 1 & 2 & 3 & 4 & 5 & 6 & 7 & 8 & 9 & 10 \\
\hline DESCRIPTION & $\begin{array}{l}\text { Primary } \\
\text { Fuel: } \\
\text { Coal }\end{array}$ & $\begin{array}{c}\text { Coal } \\
\text { Combustion } \\
\text { Air }\end{array}$ & $\begin{array}{l}\text { Reburning } \\
\text { Fuel: } \\
\text { Biomass }\end{array}$ & $\begin{array}{l}\text { Reburning } \\
\text { Fuel } \\
\text { Transport }\end{array}$ & $\begin{array}{c}\text { Overfire } \\
\text { Air }\end{array}$ & $\begin{array}{c}\text { Boiler } \\
\text { Bottom } \\
\text { Ash }\end{array}$ & $\begin{array}{c}\text { Economizer } \\
\text { Hopper } \\
\text { Ash }\end{array}$ & $\begin{array}{c}\text { Air } \\
\text { Heater } \\
\text { Leakage }\end{array}$ & ESP Ash & $\begin{array}{c}\text { Flue Gas } \\
\text { to } \\
\text { Stack }\end{array}$ \\
\hline GAS SIDE: & & & \multirow{6}{*}{34,841} & \multirow{6}{*}{85,984} & \multirow{6}{*}{$\begin{array}{r}331,636 \\
72,158\end{array}$} & & & & & \multirow{6}{*}{$\begin{array}{r}1,433,065 \\
287,757\end{array}$} \\
\hline Air (lbs/hr) & & 981,642 & & & & & & & & \\
\hline Air (SCFM) & & 213,586 & & & & & & & & \\
\hline Reburn Fuel (lbs/hr) & & & & & & & & & & \\
\hline Flue Gas (lbs/hr) & & & & & & & & & & \\
\hline Flue Gas (SCFM) & & & & & & & & & & \\
\hline SOLID SIDE: & & & & & & & & & & \\
\hline Primary Fuel (lbs/hr) & 93,050 & & & & & & & & & \\
\hline Fuel Inerts (lbs/hr) & 8,105 & & 61 & & & 2,042 & 408 & & 5,716 & \\
\hline Total Waste Solids (lbs/hr) & 8,105 & & 61 & & & 2,042 & 408 & & 5,716 & \\
\hline
\end{tabular}


TABLE 3-3. ADVANCED REBURNING MATERIAL BALANCE

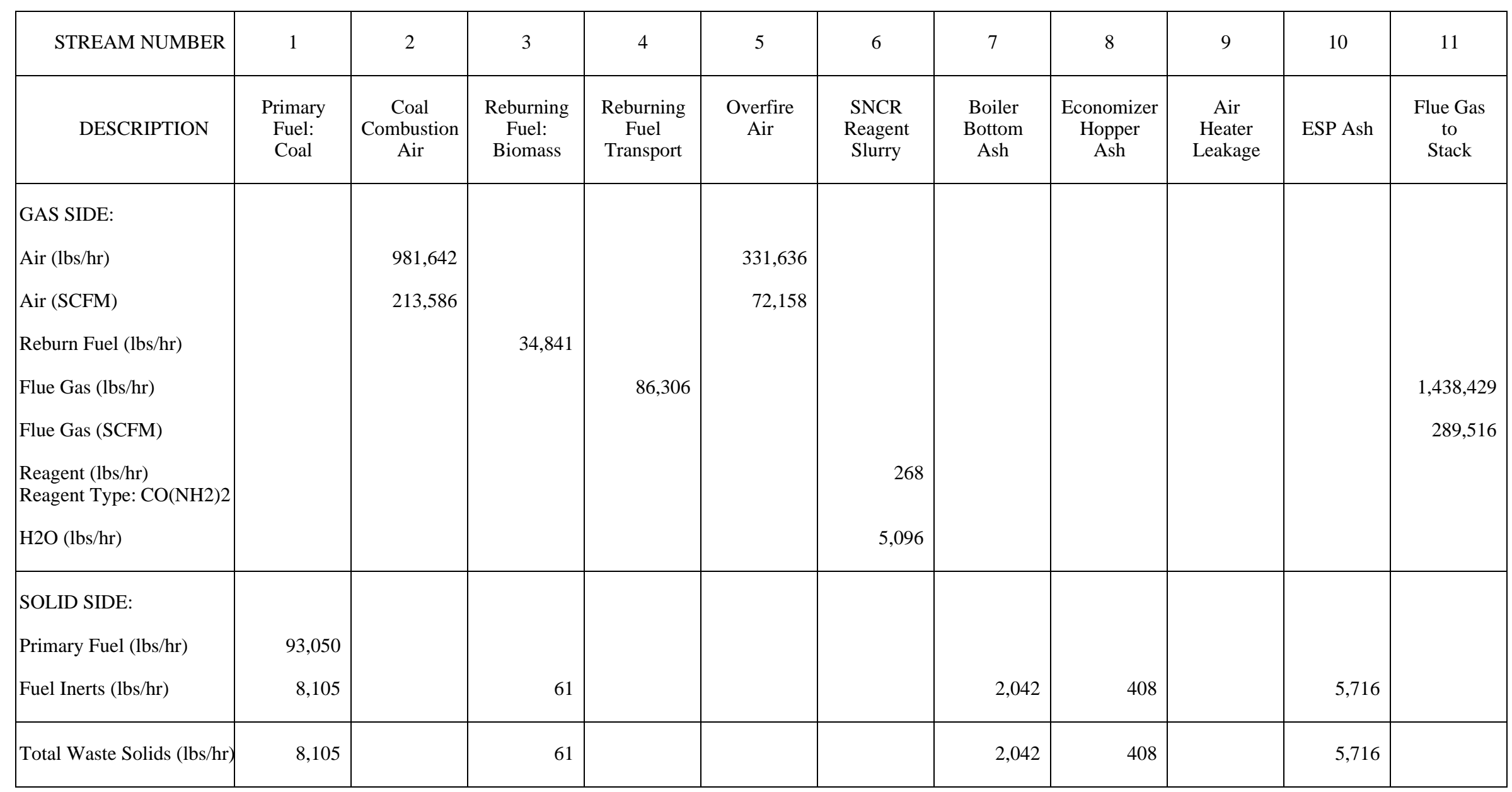




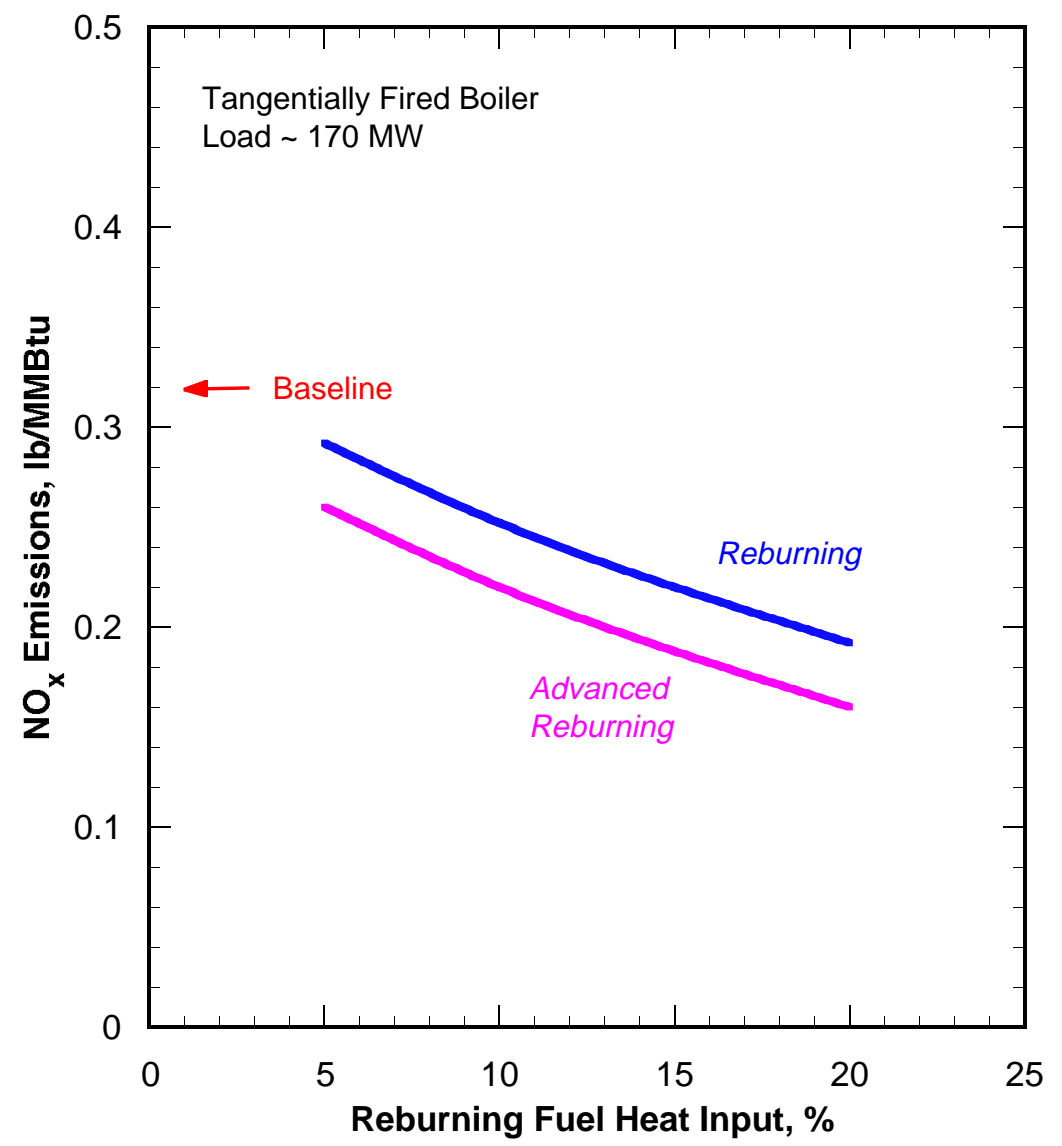

Figure 4-1. Projected performance for reburning and advanced reburning with biomass. 